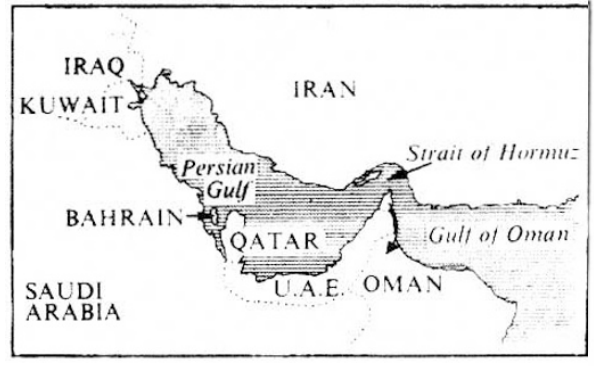

\section{Pollution in the Persian Gulf}

OIL-RICH states surrounding the Persian Gulf are discovering the gremlin of economic growth: pollution. Later this month (24 April) representatives from Bahrain. Iran. Iraq. Kuwait. Oman. Qatar. Saudi Arabia, and the United Arab Emirates meet in Kuwait. under the aegis of the United Nations Environment Programme (UNEP), to sec what they can do to clean up the Gulf and its coastline.

The size of the problem is indicated in a document released by Earthscan (an information unit supported by UNEP). In 1976. it say's. the Gulf had 142 major coastal plants in existence or planned. These included 60 refincries and similar plants associated with oil: 11 cement plants: 8 fertiliser plants: 26 desalination and power plants.

There were also stcel mills. aluminium smelters. copper refineries. plastics plants. and a titanium mill. all adding to the pollution load on a sea which averages only $34 \mathrm{~m}$ deep, with shore waters less than $10 \mathrm{~m}$ deep stretching for many kilometres off-shore.

UNEP concludes: "In this time of development boom, a number of disjointed ad hoc projects are under way. often competing for land. materials. and labour, and seemingly of no account in tomorrow's environmental conflicts."

Yet UNEP does not want to imposc on the Gulf states environmental controls which will hinder their development. Dr Mostafa Tolba. the Egyptian microbiologist who directs UNEP. told Nature last weck that he saw no conflict between environment and development. The issue was one of proper environmental management.

It is much more cconomic. Tolba said. to correct for the side effects of a development plan before it is implemented than to wait until it is too late. "It will be much more expensive and wil! cause economic de-development. not development."

A specific example would be a cement plant producing. say. 100,000) tonnes of cement a year. This emits 10-20 tonnes of waste materials into the air each day. waste which. according to a UN report, is intolerable to

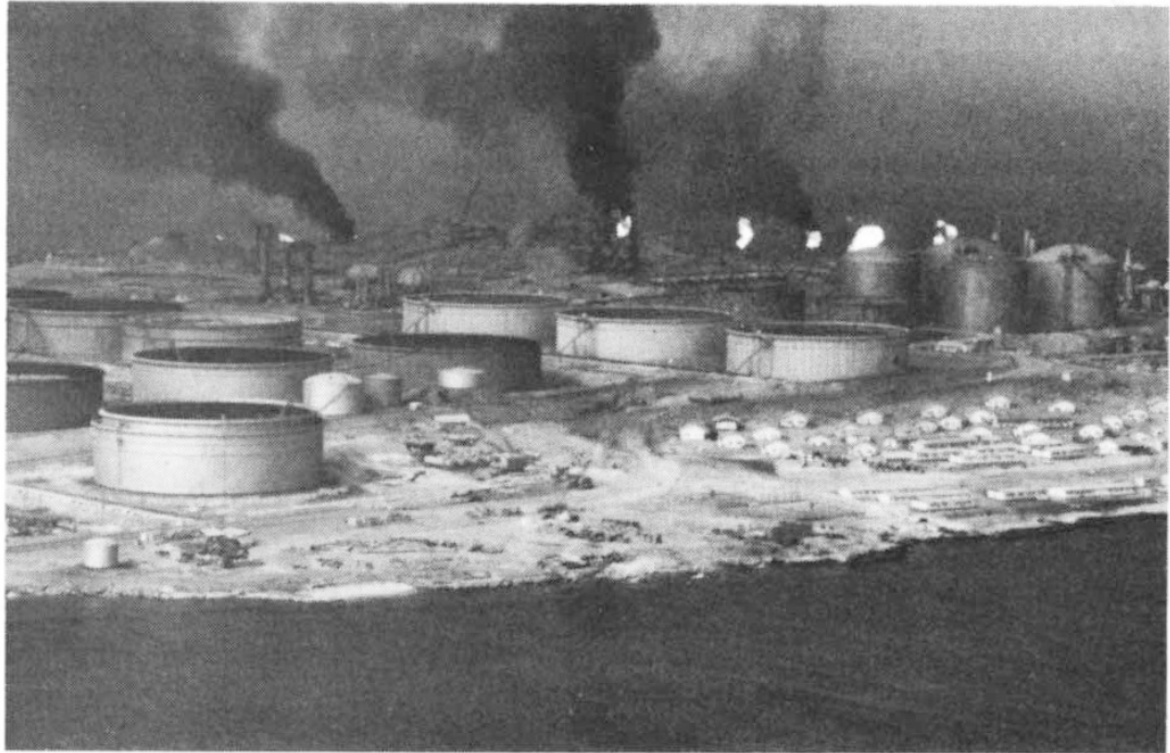

vegetable crops within several kilometres. The net bencfits of the cement plant have to be weighed against its possible costs.

According to the Earthscan report the sheer speed of development on the Gulf is part of the problem. Urban populations arc increasing at between 6 and $10 \%$ per annum, implying a Joubling in four to 10 years. (The total population increase is 500.000 a year.)

Spending is high. Industrial investment on the Arabian side of the Gulf averages $\$ 40 \mathrm{~m}$ per kilometre of coast and $\$ 20 \mathrm{~m}$ per kilometre on the Iranian side. In Saudi, investment is up to $\$ 100 \mathrm{~m}$ per coastline kilometre. Moreover, the inevitable futurc decline of oil revenues in the area is leading to a rapid diversification of industry.

Industries and agriculture need water, and the Gulf is the source and the sink for most of it. It is warm. shallow, long and thin $(1.200 \mathrm{~km}$ by some 75 to $350 \mathrm{~km}$ ) and closed by the narrow 62-km Strait of Hormuz. The water balance is maintained from the Gulf of Oman, as the evaporation from the Gulf exceeds the inflow from rainfall and rivers.

Evaporation of the surface waters also cizuses them to sink. creating pollution traps: and the sea has the world's greatest concentration of desalination plants, sending fresh water to the land but highly saline water to the sea. It is thus not surprising that UNEP believes that the sea's capacity for breaking up and digesting industrial and urban waste is poor.

The coastal ecosystems have been little investigated. but. according to the 1976 UNEP mission quoted by Earthscan: "If coastal urbanisation. untreated sewage effluent, industrial wastes and heated water, plus brine discharge from desalination plants continue to increase at the present pace, many ecological problems will be compounded beyond recovery."

It is against this background that the coastal states meet-and none too soon. According to one Middle East expert they could have come together two years ago, if they had been able to decide what to call the Gulf. The "Persian Gulf" (its usual geographic name) offended the Arabs, the "Arabian Gulf" the Persians, and now even the compromise "Gulf" is rejected by Iran (for its omisssion of "Persian"). UNEP is now calling the Gulf "The Region".

At the Kuwait meeting, the states will discuss an "action plan" and two environmental protection treaties. The first treaty pledges the states to "prevent, abate and combat pollution" and the second to cooperate in case of emergency. (A shipping accident is not out of the question: the Gulf contained 26 oil-loading terminals in 1976 and 100 vessels a day were entering the Straits of Hormud. Harbours are so congested that ships have to wait weeks before they unload.)

The centre of the action plan is a programme, similar to a highly successful one in the Mediterranean, to rescarch the extent and effect of pollution in the Gulf. It also deals with development--for example of water management, solar energy, and aquaculture.

Dr Peter Thacher, deputy executive director of UNEP, said recently "The development of a programme for the protection of the sea and coasts [of the Gulf] requires a scientific assessment of the current quality of the environment and a survey of the capabilities of the region's marine scientists and laboratories. The provision of technical assistance. training and equipment will be an essential feature of the programme." 